\title{
CLUSTERS AS A TOOL OF COOPERATION AND FORMATION OF REGIONAL NETWORKS: EVIDENCES FROM SLOVAKIA
}

\author{
BARBORA NÉMETHYOVÁ, ZUZANA DOLNÁ \\ Faculty of Humanities and Natural Sciences, Prešov University \\ 17, November Street, 08001 Prešov, Slovakia \\ e-mail: barbora.nemethyova@gmail.com zuzana.dolna@gmail.com
}

\begin{abstract}
The importance of developing global and local networks and business clusters between firms and companies in order to reach competitiveness has recently become one of the most significant issues in modern economies. Geography plays an important role in this field because it places all these networks into particular space and territory, giving them specific characteristics.

In the last two decades, firms and regions have actively engaged in networks to survive in global markets and to pursue sustainable development. However, due to the individualism of companies and the lack of knowledge of potential benefits of networking, cluster theories are still neglected as a tool for enhancing the regions `qualities and competitiveness in less developed countries. Furthermore, the theoretical information is not systematized but rather fragmented, it is insufficient and empirical studies are limited, too.

The aim of this paper is to examine the role of networking and to provide a kind of background theory for further empirical research. First of all, it will summarize basic knowledge and theories about clusters and networks based on available literary sources. Clusters are not easy to define and their classification is also not so clear, therefore this paper endeavours to clarify basic definitions, dynamics and typology of clusters and levels of networks so that it can serve as a conceptual frame for further empirical research. Finally, it will try to examine whether such clusters and networks do really exist in the Slovakian context and if they do, then whether they are comparable to those in Western European countries.
\end{abstract}

Key words: clusters, cluster policy, regional development, networks, Slovakia

\section{THEORETICAL-METHODOLOGICAL FRAME OF CLUSTER ISSUE}

\section{NETWORK SOCIETY}

Recent period of regional politics is typical for its significant representation of institutional and neo-liberal approaches. Castells (1996) introduces the theoretical concept of network society. He claims that there are relations between culture, politics, 
economics, society and information technologies, which influence and change the society significantly. In economic sphere, the formation of network economics becomes a mean of success. The analysis of networks is regarded as a tool of understanding the regional dynamics and development since the 1990s. Therefore, it is necessary to stress the analysis of relations between the actors in society, social context and tangible as well as non-tangible linkages. These can be formal, informal, personal, institutional, etc.; and under the basic linkages we understand competition, cooperation and governance. Network organization is therefore a predominant form of ordering and organization of society and economy and is manifested geographically in the forms of strategic alliances, clusters, innovational networks, informal networks, etc. They are flexible enough to be modified according to the market conditions without losing their organizational and juridical subjectivity. The development of network enterprising was enabled mainly by the evolution in the field of information and communication technologies. Zadražilová et al. (2004) defines the network enterprising as a mutual interconnection of complementary enterprises, in which the enterprises work together on formation of a final product; they can for example cooperate in research and development, create mutual logistic solutions, etc., but economically they remain autonomous and self-reliant. They can include research institutes, educational and training institutions and administrative bodies in such networks. The success of network enterprising is conditioned by mutual cooperation, trust, initiative, abilities and flexibility. Particular representations and forms of networks are continually developing, forming new and more complex forms of cooperation enterprising such as clusters.

\section{CLUSTERS IN REGIONAL DEVELOPMENT}

Increasing global economic integration accentuates the emphasis on regional and local potential. Clustering of similar enterprises existing in one region provides decrease of transport costs, barrier elimination, total external savings and collective effectiveness. Therefore, it is possible to observe a raising importance of regional economics and the importance of place in them. The real reflections of these tendencies are the cluster phenomena.

Clusters were introduced into economics and regional development by Porter (1990), who presented them as a basic tool of industrial and regional policy and a way how to reach the competitiveness of regions and states. Clusters are directly connected to the issue of innovation, in other words, they are a tool of innovation policy. Although they cannot be regarded as a be-all and end-all to all the problems in economics and regional development, they are definitely a stimulus of economic growth and competitiveness. The most popular representatives of innovative centers and clusters are: Silicon Valley, Route 128 and Research Triangle in USA; Emilia Romagna and Veneto regions in Italy; Montpellier, Sophia-Antipolis, Grenoble and Toulouse in France; M4 Corridor in south England; Freistaat in Germany, north-east of Spain, central part of Portugal and alike. 


\section{HISTORICAL BASES OF CLUSTERS}

Theoretical sources of cluster concepts reach as far back to the 19th century, when the British economist Alfred Marshall introduced his idea that the industrial sectors are often spatially concentrated and gain assets from externalities, such as savings from area size and spillovers, as a result of these concentrations. In the following period, the so-called "industrial districts" became a determining phenomenon, being regarded a forerunner of clusters. Throughout the whole 20th century many authors such as Weber (1909), Christaller (1933), Schumpeter (1942), and others, dealt with economic efficiency, concentration of industry and similar concepts. Society passed continually from the period of extensive accumulation in 19th century, through the accumulation regime according to ford principles up to flexible accumulation typical for its flexible production, emphasis on technology development, qualification of workforce and organizational structure of an enterprise in the form of networks. Almost a century after the Marshall idea of industrial districts, the first modern industrial districts appeared in Italy and consecutively Porter's neo-marshall concept of clusters had a significant influence on the study of regional and local clustering, sector specialization, innovations and enterprises and became a basic tool of regional politics and local competitiveness. From the temporal point of view, the longest traditions of clusters issue are in the northern districts of Spain, where the first pioneering cluster program was introduced in 1986 under the leadership of Porter himself.

\section{DEFINITIONS OF CLUSTERS}

- Industrial or sector clusters are, according to Porter (1990), geographic concentrations of interconnected companies, specialized suppliers, service providers, firms in related industries and associated organizations (such as universities, standard agencies, trade associations) in a particular field linked by commonalities and complementarities. There is a competition as well as cooperation between them.

- Clusters are formed by a group of companies of the same or similar sector of industry located in the same region. In every cluster we can find mutual labour market, mutual market for companies' input and also transfer of information and technologies between companies (Skokan 2006).

- Roelandt and Hertog (1998) perceive clusters as production networks of largely depending companies, including specialized suppliers, interconnected within the production chain. In some cases they also include strategic alliances with universities, research institutes, mediating organizations and customers.

- UNIDO (United Nation Industrial Development Organization) (2001): Clusters are sectoral and geographic concentrations of companies, which produce and sell similar or complementary goods and together they face the challenges and priorities. These concentrations of companies enable them to arrange external savings.

- EU (DG Enterprise EU) (2003): Clusters are groups of independent companies and associated institutions, which cooperate and compete. Geographically they are located in one or more regions, or they can have a global scope; they are spe- 
cialized in a particular field and are interconnected by mutual technologies and mutual qualification; they exist in traditional sectors or they have scientific basis. Clusters can be institutionalized or spontaneous. They positively influence innovations, competitiveness, qualification, information, growth and long-term business dynamics.

- White Book of cluster policy (2004) introduces seven basic elements characterizing clusters:

- local concentration - companies are located in geographic vicinity

- core of cluster and its specialization - clusters are concentrated around a key activity

- members of cluster - representatives of industry, public administration, academic sphere and financial sector

- cluster dynamics and linkages - relations of competitiveness and cooperation between actors

- critical number of subjects - to keep the internal dynamics of a cluster

- cluster life-cycle

- innovations

Some authors (e.g. Cortright 2006) come to conclusion that it is not possible to define cluster exactly and synthetically, because the definition must be modified according to the purpose of the work that deals with the issue of clusters. Due to the fact, that clusters vary according to particular regions and sectors, it is more convenient to perceive them as a general concept rather than an exactly defined notion.

\section{CLUSTERS CLASSIFICATION AND LIFE-CYCLE OF CLUSTERS}

Partial typology of clusters was introduced in the aforesaid definitions of clusters. According to Porter (1998) we can classify clusters according to size, width or development status. Some clusters are composed of small or medium enterprises, the others include also large companies. Some clusters are concentrated on research universities, while the others have no relations with universities at all. These differences result from structural industries they are formed of. More developed clusters have deeper and more specialized baseline of suppliers, wider area of similar industries and more supporting institutions. Enright (2003) characterizes clusters from the point of view of the following dimensions:

- Geographic scope or size: is related to the spatial distribution of companies, customers, suppliers, services and institutions, which are a parts of a cluster and its activities. From the geographic point of view we therefore differentiate local, regional, sub-regional, national and international (or cross-boundary) clusters.

- Density: is related to the number and economic strength of companies in a cluster.

- Width: includes horizontal industries within a cluster

- Depth: includes vertical industries within a cluster i.e. suppliers' chain

- Geographic scope of market: defines the distance of cluster activities' influence

- Baseline of activities: includes number and character of the activities in a network, which are performed in conjunction with a region 
- Strength of competitive position: cluster can reach a scope from world leading, through supra-nation leading, to national level.

- Degree of development: cluster can be embryonic, growing, mature, stagnant and retrograde.

- Technologic activities in cluster: clusters can be technology generators, technology adaptors or technology users.

- Innovation capacity of cluster: it is the ability of a cluster to produce key innovations which are relevant to competitiveness and are of subject interest of a cluster.

- Structure of ownership: defines whether a cluster is formed of companies in local ownership, owned by foreign investors or the combination of both of them.

Some analysts (Rosenfeld 2002, Enright 2003) differentiate following clusters:

- functioning - clusters that were identified and their members are aware of them.

- latent-represent opportunities for future, which were not exploited yet.

- potential-accomplish some conditions, but they absent some inputs and critical level of some factors

Enright (2003) introduces also:

- politically formed clusters - clusters chosen and supported by policy, because they absent critical level of companies and conditions for their natural development

- "wishful thinking" clusters - politically directed clusters, which absent except for the critical level of companies, also some source of advantage enabling their natural development.

Based on the industrial structure, Leeder, Sysel, Lodl (2004, in: Pavelková 2009) differentiate:

- horizontal clusters-formed by producers

- vertical clusters - formed by whole supply chain

- lateral-clusters made of several small enterprises that complete or modify the products of larger companies.

Regarding the origin we differentiate:

1.Bottom up clusters-companies begin their cooperation spontaneously and afterwards internal organization of cluster is formed.

2.Top down clusters - clusters are initiated and organized from the outside.

3. Combination of both approaches.

The cluster policies White Book (2004) describes following stages of cluster development:

1.Clustering of companies and other members-cooperation is spontaneous; the first agglomerations are formed

2.Embryonic stage i.e. emerging cluster-formation of cluster core;

3. Cluster expansion i.e. developing cluster-cluster attracts new companies, new relations and linkages are formed;

4. Maturity stage-cluster reaches critical number of members, commence interregional cooperation;

5. Transformation or dissolution of a cluster. 


\section{CLUSTERS AND THEIR INFLUENCE ON THE COMPETITIVENESS OF REGIONS}

The main economic effect of clusters' operation is, according to Pavelková (2009), their positive influence on the growth of competitiveness of companies, regions and states. While for companies, competitiveness means ability to compete with rivals in order to reach higher incomes, export ratio and quality; for regions it means the ability to form and maintain the environment supporting competitiveness and creation of companies' values as well as higher living standards of inhabitants. Clusters enable their members to improve their competitiveness and better performance by means of specialized suppliers, technologies and information, spillover of knowledge within a cluster, more stress on innovations, cluster expansion and producing spin-off companies. They provide the conditions enabling to stimulate innovations and more effective use of research and development. Břusková (2003) identifies concrete assets which clusters provide for concerned companies:

- savings from scope, possibility to share the costs and investments,

- access to specialized inputs and labour force,

- access to optimalization of supply chain,

- acquirement of new customers and market opening,

- internationalization and export increase,

- improvement of company image and better advertising,

- access to information,

- increase of innovation potential,

- growth of power and decision making of smaller companies by means of lobbing,

- access to institutions and public sources.

From the macro-economic point of view, clusters are important and efficient tool of regional policy. The level of regional development is significantly influenced by the quality of business environment and the presence of clusters. Business environment can be described by four mutually interconnected areas, introduced by Porter in its well-known diamond model. It includes: factor conditions; demand conditions; firm strategy, structure and rivalry; and related and supporting industries. Additional factors are the role of government and public sector, presence of foreign investors or the influence of neighbouring countries. Asheim, Cook and Martin (2006) completed Porter's diamond with the concept of innovations. They emphasize competition and knowledge spillovers within cluster stimulating innovation activity. Clustering then increases the innovations and the investment growth. Innovations increase productivity and higher productivity supports competitive advantage of clusters (Figure 1).

Competitiveness of regions therefore influences regionalization of public policies and conditions the shift of coordinating and decisive activities to the regional level. There are many reasons for the support of clusters in regional development; it is for instance the raise of mutual cooperation between small enterprises, cooperation with local universities and institutes; several examples of successful cluster in other regions; failure of recent approaches and others. Clusters appear as a potential for economic 
acceleration, unemployment elimination, improvement of life quality and increase of living standards and they provide real space for formation and application of innovations.

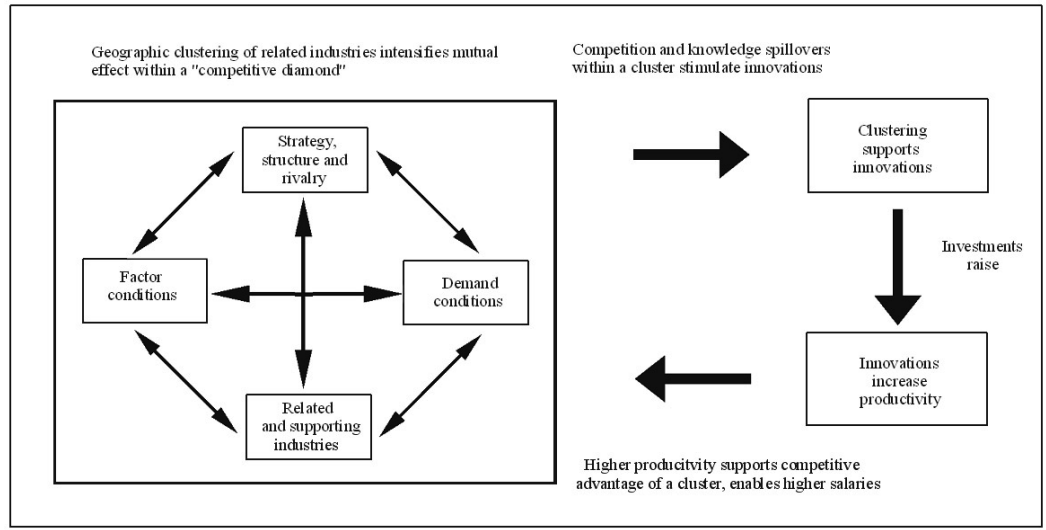

Figure 1. Porter`s Diamond and innovations in clusters

Source: Asheim, B., Cook, P. and Martin, R., (2006),Clusters and Regional DevelopmentCritical Reflections and Explorations, Routledge, Abingdon.

\section{CLUSTER POLICY}

Cluster policy is an instrument for the support of industrial development, innovations, competitiveness and growth. Through cluster policies, the government is supposed to create positive business, innovative and institutional environment sustaining the success of clusters.

Initial impulse for the clusters foundation usually comes from the initiative of a government or an industry, rarely it is proposed by a university. In developed countries the initiative comes from the government, in transforming economies it is introduced by industry and in developing countries clusters are initiated by the subsidies (Pavelková 2009).

In general, it is possible to define a cluster policy as a complex of activities (programs, strategies, procedures, laws, rules) aimed at the achievement of a particular or general goal. These activities are usually performed during a certain period of time, according to intended plan and assigned budget. Development strategies must be established on identification potential or existing bases of competitive advantage of a region. Regional policy uses clusters as a mean of gathering and activating key actors. Practically it means that regional policy should provide a frame where all the companies, organizations and public agencies are able to find mutual solutions, where information are interchanged, interactive education is provided and development of relative regional advantage is granted (Pavelková 2009).

Rosenfeld (2002) proposes seven areas that are crucial for the support of clusters: 1.mapping clusters' potential and modelling relations among the key actors;

2. supporting cluster core formation, communication channels among the members of clusters and the support of knowledge spillovers; 
3. supporting the activities for clusters' organization, formation of teams for projects, ensuring external linkages, etc.;

4. supporting the raise of qualified labour force, its education and cooperation with educational institutions, supporting regional and inter-regional cooperation;

5. supporting cluster marketing strategy to attract foreign investors, lobbing;

6. supporting innovations of products and processes, start-up companies, incubators;

7. affecting the allocation of resources and investments, supporting the research activities.

If clusters receive subsidies from public sources, these can come from various EU funds and from the budgets of central, federal, regional or local bodies. However, financial support should only be temporary, for instance for projects initiation, networking support, or new cluster activities.

\section{CLUSTER POLICY OF THE EUROPEAN UNION}

Even though clusters are predominantly national and regional phenomena, European Union tries to support their formation, development and mutual cooperation very actively. Due to the fact that clusters enable innovative companies, universities and other organizations to share the knowledge and know-how, the central aim of the European Union strategy is the reinforcement of mutual work of clusters and formation of innovative business environment.

After the year 2005 in relation to Lisbon Strategy, the European Union accepted several documents for specification and implementation of tasks, in which it emphasizes the support of clusters development. Already in the project of "Integrated Guidelines for Growth and Jobs (2005-2008)" (European Commission 2005) membership countries agreed on the implementation of mutual European initiatives in the fields of technologies, public-private partnerships and the development of regional and local clusters. "The Competitiveness and Innovation Framework Programme CIP (2007-2013)" is also aimed on the support of sector innovations specifications, clusters and application of innovation management. The European Union has traced following priorities for new Programming Period of 2007-2013: 1. regional convergence; 2. regional competitiveness; 3 . territorial cooperation. It provided almost one third of its budget to reach these aims.

Basic document defining orientation and aims of cohesion policy in the new planning period of 2007-2013 is so called "Community Strategic Guidelines for Cohesion Policy (EC, 2006)". It states three basic priorities: 1. raise of the attraction of membership countries, regions and towns by improving their quality of services and protection of environment; 2. support of innovations, enterprising and growth of economics established on the education and research activities; 3. providing more and better jobs, investments to human capital. Strategic bases also emphasize developing so called "Poles of Excellence", which are supposed to join small and medium 
enterprises in the field of progressive technologies with the research and technical institutes; they emphasize development of regional clusters concentrated around large-scale enterprises and clusters of innovative enterprises. Based on the "Community Strategic Guidelines for Cohesion Policy" all the countries of EU prepared the "National strategic framework", a document in which they defined their own priorities for the use of structural funds of EU in 2007-2013.

European presidential conference on innovations and clusters in Stockholm on January 2008 proposed "European Cluster memorandum" (2008), where it has encouraged to prompter reaction on new appeals of clusters in Europe.

Initiation of "European Cluster Alliance-ECA" by European Commission in September 2006 was another very important step in cluster policy. Its main intention is to boost practical cooperation among regional governments of 55 regions and encourage them in identification and sharing experience. ECA exists in four parallel networks of cluster policy:

1.CEE-ClusterNetwork-involves 11 regions of Central and Eastern Europe.

2. CLUNET network-involves 15 regions and 64 top clusters. Its aim is to share the experience and realize particular pilot projects. The network is inspired also by Canadian experiences in cluster policy thanks to the Montreal Metropolitan Community participation.

3. INNET network-is aimed at the support of cross-border cooperation of small and medium enterprises in technology clusters.

4.BSR-INNOnet network-is aimed at the formation of linkages in the field of innovations between politicians, implementation agencies and analysts within Baltic Sea region.

Further activities are performed by European Cluster Observatory. Its aim is to inform politicians and researchers of the world about the European clusters and cluster policies. Observatory proposes information about the geographic division of clusters specialization, cluster mapping, cluster organizations, cluster policies, etc. It includes the European Union countries, Switzerland, Turkey and Israel.

\section{CLUSTER POLICY IN SLOVAKIA}

In Czech Republic, Slovenia and Hungary, programs for the support of networking in regional policy and clusters foundation have been developed since 2000. A major role in governing is provided by national and regional governments. In the conceptual frame of the European Charter of small and medium enterprises, Slovak Republic has also initiated the implementation of programs for strengthening technology capacity, innovative capacity and mutual cooperation of small and medium enterprises, public sector and research institutions, mainly universities. One of the most successful forms of such cooperation are clusters, as tools of formation regional networks and regional policy. In Slovakia we may identify the following clusters (Figure 2): 


\section{CLUSTERS IN SLOVAKIA}

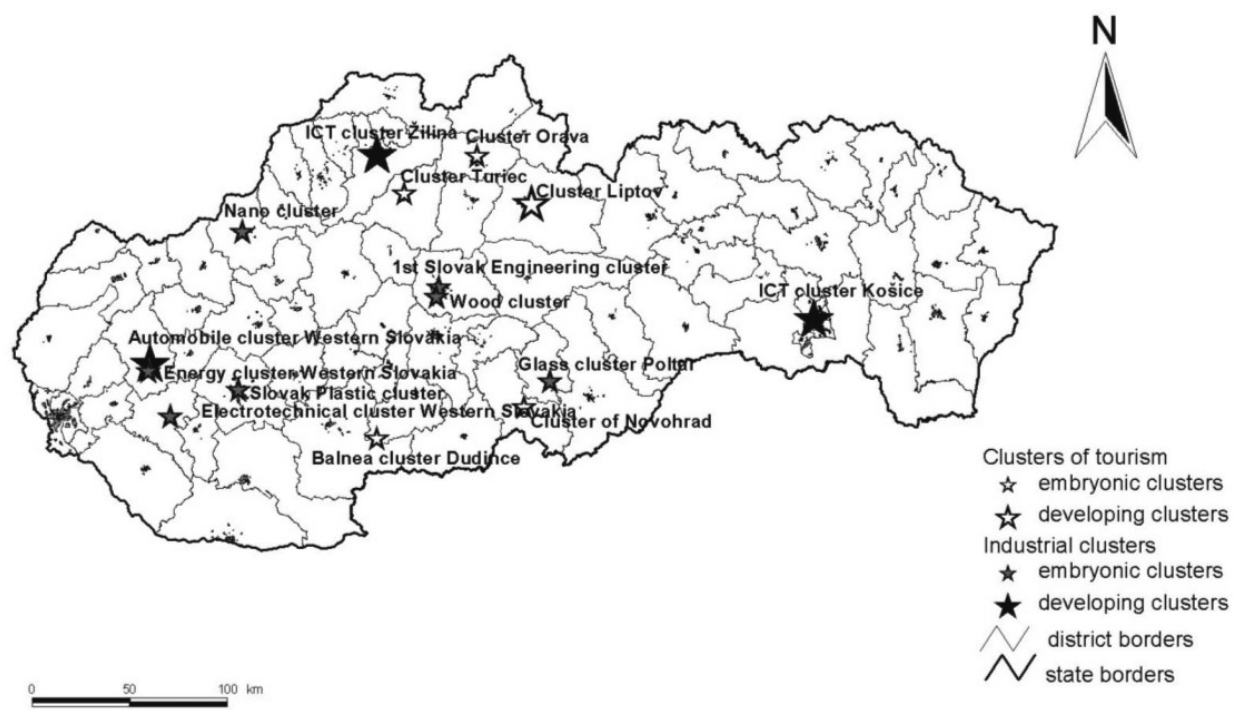

Authors: Barbora Némethyovà, Zuzana Dolná

Figure 2. Localization of existing clusters in Slovakia

Source: authors (2009).

Automobile cluster-Western Slovakia with the seat in Trnava was established in November 23rd, 2007 by Trnava self-governing region and the town of Trnava. Its vision is to develop a prestigious and modern base for automobile industry in western Slovakia until 2012. It is supposed to ensure not only the production of automobiles, but also the development of science, research and education for industry, transfer of technology and innovative processes, support of supply chains and quality of human resources. Nowadays, it provides consulting, arranges meetings, symposiums, mutual purchase and marketing and team solutions of problems for its 28 members. It participates actively on projects AC Centrope, Autoplast, Autoclusters, AutoNet and Simatic.

IT cluster Košice was established by 7 private enterprises, Košice self-governing region and 2 universities in 2007. The aim of the corporation is to build a centre of excellence for information and communication technology in Eastern Slovakia and to make the social-economic sphere of the region more attractive especially for young people. At the same time, it wants to contribute to formation of educated society in Eastern Slovakia, to establish active communication base among private enterprises, public administrative and educational institutions, which will enhance the development of IT industries in the region. It develops the concept of "learning regions". Nowadays it has 20 members.

ICT cluster Žilina was formed in May 22nd, 2008. It is supposed to stimulate the employment and education quality and to reach the competitiveness of the com- 
panies working in the field of information and communication technologies. So far it is comprised of 12 members of private, academic and public sector.

1st Slovak Engineering cluster was established by engineering companies, supporting firms and technical secondary schools in Banská Bystrica self-governing region, the Office of self-governing region and Technical University in Zvolen in September, 17th, 2008. Its vision is to build a highly prestigious and modern engineering base competent in terms of human resources, new technologies and innovations for the rise of supply chains in the field of strategic projects in construction engineering, transport industry, forestry and agriculture.

Slovak Plastic cluster in Nitra was established in March 13th, 2009. The industry of plastic production and processing is represented by a number of small and medium enterprises, which are joined in the supply chain.

Electrotechnical cluster-Western Slovakia was formed in March 19th, 2009 by Trnava self-governing region and the town of Galanta. The main impulse was driven by the presence of Samsung company and its suppliers in the region. The foremost interest is sustainable development of economics in the region with implementation of research results, the use of energy sources and region infrastructure, products specialization and continually increasing number of students with education in electric engineering.

Energy cluster Western Slovakia was formed in July30th, 2009 again in Trnava self-governing region. It focuses on the use of energetic potential in region and emphasizes renewable energy sources. In close future, it is supposed to build number of facilities using and processing water energy, biomass, solar energy, geothermal energy, waste or wind energy.

Nano-cluster Trenčín and Wood-cluster in Banská Bystrica were theoretically conceived and their real existence is assumed in close future. In July 2009, Banská Bystrica self-governing region in cooperation with enterprises in the field of glass industry decided to initiate Glass cluster in Poltár. At present they work on proposals and business objectives; cluster establishment is planned in October.

Foundation of clusters in the field of tourism has become very popular phenomenon in Slovakia recently. The first pioneer in this context was Cluster Liptov, which became an ideal example and a model for other tourism clusters in a very short period of time.

Cluster Liptov- the association of tourism tries to build a considerable destination of tourism out of the Liptov region with a strategic aim to increase the attendance of Liptov at least to a double in 2013. The association was registered in August, 8th, 2008 and it operates as a Destination Management Organization-DMO. It works as an official marketing and organizational centre, coordinates development of tourism on regional level supporting it as a separate sector in the region. There are four significant subjects of private sector in Liptov: Thermal Park Bešeňová, Aquapark Tatralandia, Jasná Nízke Tatry and Skipark Ružomberok; together with three towns: Liptovský Mikuláš, Liptovský Hrádok and Ružomberok were the founders of 
the cluster. Their ambition is to create an international cluster with Poland including the area of High Tatras. In July 2009 another three distinguished members joined the cluster.

Balnea Cluster Dudince was established in 2008 as the first spa cluster in Slovakia with the aim to coordinate its members in realization of tourism policy in the town Dudince and its surroundings; to provide informational and advisory services; to organize various undertakings and performances for the visitors of Dudince and surrounding; to foster cultural, folklore, social and leisure-time activities in the town. The members are: town of Dudince, Banská Bystrica self-governing region, Dudince Spa, Slovthermae, Hotel Hviezda, Hotel Prameň, Hotel Flóra, Park Hotel Hokovce.

Cluster Orava was established in June 2009 by 9 subjects including ski centres, hotels, guest-houses, Dolný Kubín aquapark and Zuberec village and is opened to all the subjects of Orava region. The main aim is the organization of mutual tourism marketing and the offer of tourism products, which is supposed to begin actively in the winter season 2009/2010. Cluster will represent and develop the unique brand of Orava.

Cluster Turiec was formed at the same period of time stating the same aims and ambitions. Its founders were ski parks Snowland, Jasenská dolina, Winterpark Martinky, towns of Martin and Vrútky and Fatra Ski travel agency. Paradoxically, famous Turčianske Teplice spa did not join the cluster due to some personal conflicts.

Cluster of Novohrad was established within the frontier euroregion Neogradiensis in Lučenec district. The cluster is aimed at the development of rural tourism and should contribute to economical and social raise of the region.

Cluster of tourism Western Slovakia was formed in 2008 and at present time they adress relevant subjects, which might become eventual members of the cluster. In May 2008, municipal corporation of Banská Bystrica approved the formation of three clusters in tourism: Cluster of Pohronie-Hronsek, Vlkanová, Banská Bystrica, Cluster of winter recreation-Tajov, Králiky, Kordíky, Banská Bystrica and Cluster of recreation-Banská Bystrica, Donovaly, Harmanec. However, funding of the project has been rescheduled to 2010 .

\section{CONCLUSION}

It is necessary to sum up that the implementation of cluster policy in Slovakia has already started and the establishment of clusters is realized more or less at regional level. Regarding the size, most of the clusters are rather local or regional. All of them are initiated and organized from the outside; it means they have been created as top-down clusters. Main floaters and founders are private enterprises, self-governing regions and towns. In comparison to other countries of the European Union, Slovakia still tails away in number of cluster initiatives as well as in the operation of exist- 
ing clusters. While according to Pavelková (2009) there are 45 clusters in Austria, in Slovakia there are only 16 of them. Furthermore, clusters are formed of less number of members. Mature clusters in Austria have more than 400 members, however in Slovakia their number varies up to 20. One of the reasons why subjects ignore joining such initiatives is the lack of milieu of trust from the side of private entrepreneurs and refusal of mutual cooperation and mutual aims due to the fear of losing their own business strategy on behalf of mutual know-how. Connection of producers with the universities and research institutes is, except for the ICT clusters, very weak. Considering the degree of development, Slovak clusters are rather embryonic or growing. Based on the classification of sector structure, typical vertical cluster involving whole supply chain is Automobile cluster-Western Slovakia; the others are rather horizontal, formed of producers and service suppliers and they do not cover whole supply chain.

Specific category is represented by clusters of tourism, which have become very popular form of cooperation recently. The number of their members is usually very low and direct connection to the educational or research institutions practically does not exist at all. However, they are very effective form of cooperation and Cluster Liptov proves their success.

Evaluation of existing clusters involves review of their activities such as networking, human resources, research and development, innovations, teamwork and cooperation, information and technology transfer between companies, etc. Due to the limits of this contribution it is not possible to provide such an intricate analysis of identified clusters. In spite of this, it is necessary to stress that network policy and implementation of clusters initiatives appears to be a successful approach in regional policy.

\section{ACKNOWLEDGEMENT}

This paper was prepared with the contribution of the grant: VEGA no. 1/0611/09 "Koncept miesta v regionálnogeografickej analýze a syntéze a teritoriálnom marketingu: teoreticko-metodologický rámec a aplikácia na vybrané modelové územia” (leaded by R. Matlovič).

\section{REFERENCES}

Anderson, T., Schwaag-Serger, A., Sorvik, J. and Hannson, E. (2004), The Cluster Policies Whitebook, IKED, Sweden.

Asheim, B., Cooke, P. and Martin, R. (2006), Clusters and Regional DevelopmentCritical Reflections and Explorations, Routledge, Abingdon.

Automobilový klaster západné Slovensko, <http://www.autoklaster.sk/index. php?option=com_frontpage \&Itemid = 1 >,navštívené 15.8.2009 
Blažek, J. and Uhlír̆, D. (2002) Teorie regionálního rozvoje, Univerzita Karlova v Prahe, Karolinum, Praha.

Břusková, P. (2003), Průmyslové klastry. Nová strategie zvyšovaní konkurenceschopnosti a regionálního rozvoje. Informační brožura $k$ problematice průmyslových klastrů, Ostrava, <www.jic.cz/soubory/knihovna/prumyslove_klastry.pdf.>

Buček, M. et al. (1992), Priestorová ekonomika. Edičné stredisko, Ekonomická Univerzita v Bratislave, Bratislava.

Castells, M. (1996), The rise of the network society, Blackwell Publishers, Oxford, UK. Castells, M. (1997), The power of identity, Blackwell Publisher, Oxford, UK.

Cloke, P., Philo, Ch. and Sadler, D. (1991), Approaching human geography. An introduction to contemporary theoretical debates, Guilford Press, New York.

Cortright, J. (2006), Making sense of clusters: regional competitiveness and economic development, Impresa, The Brooking Institution Metropolitan Policy Program.

Energetický klaster Západné Slovensko,<http://trnava.sme.sk/c/4954003/energetickyklaster-ma-zvysit-konkurencieschopnost-firiem.html>, navštívené 15.8.2009

Enright, M. J. (2003), Regional Clusters: What we know and what we should know, in: Brocker, J., Dohse, D., and Soltwedel, R. (eds.) (2003), Innovation clusters and interregional competition, Springer-Verlag, Berlin.

EU (2003), Final Report of the Experts Group on Enterprise Clusters and Networks, Brussels, Enterprise DG, <http://europa.eu.int/comm/enterprise/entrepreneurship/support_measures $>$

European cluster memorandum. Promoting European innovation through clasters (2008), The High Level Advisory Group on Clusters.

European Commission (2005), Integrated Guidelines for Growth and Jobs (2005-2008), European Communities, Luxembourg.

Haggett, P. and Chorley, R. J. (1969), Network analysis in Geography, Edward Arnold Publishers, London.

Hampl, M. (1989), Hierarchie reality a studium sociálnegeografických systémů, Rozpravy ČSAV, 99, Academia nakladatelství ČSAV, Praha.

Hubbard, Ph., Kitchin, R., Bartley, B. and Fuller, D. (2005), Thinking geographically, Continuum, London.

IKT klaster Žilina, < http://www.zaict.sk/>, navštívené 15.8.2009

Iniciatíva Cluster Linked over Europe (2006), Information about clusters, dostupné na: <http://www.clusterforum.org/>, navštívené 10.7.2009

IT Valley Košice, <http://www.kosiceitvalley.sk/index.php?ids=19>, navštívené 15.8.2009

Johnston, R. J. and Sidaway, J. D. (2004), Geography and geographers. Anglo-American human geography since 1945, Arnold, London.

Johnston, R. J., Taylor, P. J. and Watts, M. J. (2002), Geographies of global change remapping the world, Blackwell Publishing, Oxford.

Klaster Liptov, <http://www.klasterliptov.sk/> : navštívené 18.8.2009

Kodríková, E. (2008), Zakladáme strojársky a drevársky klaster, <http://www.vucbb. 
sk/ganet/vuc/bb/portal.nsf/wnovinky/7ef1c9b04fafb08ac1257467002bfd0c?Open Document $>$, navštívené 3.9.2009

Kopka, R. and Kovalčíková, J. (2009), Klaster Turca má prilákat turistov, <http://turiec. sme.sk/c/4908614/klaster-turca-ma-prilakat-turistov.html >, navštívené 25.8.2009

Mlčoch, L. (2005), Institucionální ekonomie, Karolinum, Praha.

Molnár, P. (2004), Innovation management, Ekonóm, Bratislava.

Murdoch, J. (2006), Post-structuralist geography, Sage Publications, London.

Novohradský klaster, <http://www.rra-lc.sk/?p=429>, navštívené dňa 25.8.2009

Oravský klaster, <http://relax.etrend.sk/relax-cestovanie/dalsi-klaster.html>; $<$ http://www.slovakia.travel/data/Resources/Upload/Doc/Novinky/Klaster\%20 Orava\%20zalozeny.rtf>, navštívené 12.8.2009

Pavelková, D. et. al. (2009), Klastry a jejich vliv na výkonnost firem, Grada Publishing, a.s., Praha.

Plastikársky klaster Nitra, <http://www.plasticportal.eu/sk>, navštívené 15.8.2009

Porter, M. (1990), The competitive advantage of nations, The Free Press, New York.

Porter, M. (1993), Konkurenční výhoda, Victoria Publishing, Praha.

Porter, M. (1998), On Competition, Harward Business School Press, Boston.

PRO INNO Europe, CLUNET (2007), Cluster Policy Guidelines Report, <www.proinnoeurope.eu/admin/uploaded_documents/CLUNET_policy_Guidelines_080108. pdf.>

Regional clusters in Europe, EC (2002), Synthesis report cluster mapping, Cluster observatory, <http://www.clusterobservatory.eu/upload/Synthesis_report_cluster mapping.pdf $>$

Roelandt, T. J. A. and den Hertog, P. (eds.) (1998), Cluster analysis and cluster-based policy in OECD countries, OECD Focus Group, Hague-Utrecht.

Rosenfeld, S. (2002), A Governor's guide to cluster based economic development, National Governors Association Washington.

Ružičková, M. (2009), Najväčś záujem je o kúpele a vodnú turistiku, <http://hnonline.sk/c1-36926520-najvacsi-zaujem-je-o-kupele-a-vodnu-turistiku>, navštívené 22.8.2009

Skokan, K. (2006), Regionální inovačni systémy a klastry v rozvoji regionů, Inovativní koncepty s socioekonomickém rozvoji územnich jednotek, Sborník příspěvků, Universitas Ostraviensis, Ostrava.

Šmíd, J. (2008), Nano-klaster Trenč́n, < http://www.nanosvet.sk/_paper/Nanoklaster. pdf >, navštívené 18.8.2009

TASR (2009), Samosprávny kraj a Galanta založia elektrotechnický klaster, <http://openiazoch.zoznam.sk/info/zpravy/zprava.asp?NewsID=60319>, navštívené 15.8.2009

TASR (2009), Založenie sklárskeho klastra v Poltári napreduje, <http://dnes.atlas.sk/ ekonomika/podnikanie/578551/zalozenie-sklarskeho-klastra-v-poltari-napreduje>, navštívené dňa 3.9.2009

UNIDO (2001), Development of clusters and network of SMEs, The UNIDO Programme, OECD, Vienna. 
Wokoun, R., Malinovský, J., Damborský, M., Blažek, J. et al. (2008), Regionálny rozvoj, Linde, Praha.

Zadražilová, D. et al. (2004), Mezinárodní management, Nakladatelství Oeconomica, Praha. 